\title{
Optimization of extraction process for efficient imino acids recovery and purification from low-value sea cucumber
}

\author{
Hai-Yan ZHOU ${ }^{1,2}$, Ya-Li ZHANG ${ }^{1,2}$, Sai-Jun LIN ${ }^{1,2,3}$, Ya-Ping XUE ${ }^{1,2}$ (D), Yu-Guo ZHENG ${ }^{1,2 *}$
}

\begin{abstract}
For high recoveries and purities of L-proline (L-Pro) and L-hydroxyproline (L-Hyp) from the low-value sea cucumber Acaudina leucoprocta, the extraction process was systematically investigated and optimized. The results indicated that, in decoloration of A. leucoprocta hydrolysate, activated carbon powdered W660 was more suitable due to the low addition amount and short treatment time compared with macroporous resin HZ816 offering comparable decoloration ratio and imino acids recovery yields. For oxidative deamination, $\mathrm{HCl}-\mathrm{HNO}_{3}$ exhibited better performance than $\mathrm{NaNO}_{2}$ with complete primary amino acids broken-down and fewer imino acids loss. After decoloration and oxidative deamination under their optimized conditions, an extraction solution was obtained with L-Pro and L-Hyp recovery yields of $76.3 \%$ and $78.8 \%$ from A. leucoprocta hydrolysate, which was directly used for separation of L-Pro and L-Hyp with ion-exchange chromatograph. This work may be referenced for the large-scale L-Pro and L-Hyp production from other low-value materials.
\end{abstract}

Keywords: Acaudina leucoprocta; extraction; recovery; L-proline; L-hydroxyproline.

Practical Application: A. leucoprocta can be potentially used as raw materials for large-scale preparation of imino acids.

\section{Introduction}

The sea cucumber Acaudina leucoprocta H. L. Clark (Echinodermata: Holothuroidea: Molpadida: Caudinidae) is one of the most common sea products in Asia (Liu et al., 2017, 2018). It possesses a purple-brown and spindle-shaped body, generally $10-14 \mathrm{~cm}$ long, with a white posterior and cloacal lining (Clark, 1938). It contains a variety of active components and has high nutritional and pharmaceutical values comparable to Stichopus japonicas (Shan et al., 2013). However, due to long living in the submarine silt, its body wall is covered by dense and stiff dirt, in which seabed silt and mucus secreted from the surface of A. leucoprocta were strongly linked, influencing the food value of A. leucoprocta (Shan et al., 2013). Additionally, rapid developments of industrialization and urbanization have generated severe marine pollution, causing increased contents of toxic heavy metals $(\mathrm{As}, \mathrm{Hg}, \mathrm{Pb}$, and $\mathrm{Cd}$ ) in the surface of A. leucoprocta (Lin et al., 2018). The consumption of A. leucoprocta has been drastically hampered (Huang et al., 2007). Up to a million tons of A. leucoprocta have been harvested from the East China Sea and discarded as waste by the local fishermen for many years (Lin et al., 2017). Therefore, optimized utilization of these polluted $A$. leucoprocta is necessary, especially for preparation of the valuable products.

In our preliminary investigation, $73.63 \%$ of protein and $57.59 \%$ of collagen were detected in dry matter of A. leucoprocta, respectively (Shan et al., 2013). In collagen peptides, L-proline (L-Pro) and L-hydroxyproline (L-Hyp) are more frequently found than in other proteins (Bhattacharjee \& Bansal, 2005; Lin \& Kuan, 2010). L-Pro and L-Hyp are two imino acids with strong chirality inducing properties due to their rigid conformations. Chiral compounds are one of the most important building blocks in the pharmaceutical, food, cosmetic, agricultural, and feedstuff industries (Xue et al., 2018). L-Pro is widely used for stereoselective synthesis, both in stoichiometric amounts and as a chiral catalyst (Klein \& Hüttel, 2011). L-Hyp acts as a chiral building block for the synthesis of important pharmaceutical drugs such as carbapenem antibiotics, angiotensin-converting enzyme inhibitors and antispastic agents (Chen et al., 2016; Klein \& Hüttel, 2011; Watanabe et al., 2015).

L-Hyp is manufactured traditionally through collagen hydrolysis of the land-based animals, such as cow and pig (Muralidharan et al., 2013; Yi et al., 2014). However, the emergence of bovine spongiform encephalopathy and foot and mouth disease have led to a declining supply of collagen and collagen-derived products in recent years (Huang et al., 2016; Li et al., 2013; Minh Thuy et al., 2014). Alternatively, marine organisms have been recognized as potential resources and are being explored due to their high availability, no risk of disease transmission, and high collagen yields (Lin et al., 2017; Muralidharan et al., 2013). Therefore, the polluted A. leucoprocta could serve as a realistic raw material for L-Pro and L-Hyp preparation. To date, there have been few reports that systematically investigate the extraction conditions of L-Pro 
and L-Hyp from protein hydrolysate. Therefore, to make better use of the low-value A. leucoprocta and to obtain high recovery and purity of products, the extraction process mainly including decolorization and oxidative deamination were investigated and improved for an efficient recovery and purification of L-Pro and L-Hyp from the A. leucoprocta hydrolysate.

\section{Materials and methods}

\subsection{Materials and reagents}

Dried sea cucumber A. leucoprocta were provided by Shiji Marine Products Co., Ltd. (Xiangshan, Ningbo, China). L-Pro and trans-4-hydroxy-L-proline standards were purchased from J\&K Chemical Co., Ltd. (Beijing, China). Borate buffer ( $\mathrm{pH}$ 10.2) and 9-fluorenyl methoxycarbonyl chloride ( $\mathrm{Fmoc}-\mathrm{Cl})$ were provided by Agilent Technologies (Palo Alto, USA). Acetonitrile and methanol were HPLC grade and purchased from Honywell Burdick \& Jackson Chemical Ltd., USA. Other chemicals and reagents otherwise demonstrated were of analytical grade from commercial sources.

\subsection{Decolorization agents}

Two activated carbons (powdered W660 and granular 769) and eight macroporous resins including X-5, HZ816, D101, DA-201C, HPD-722, AB-8, S-8 and NKA-9 were used for decoloration of A. leucoprocta hydrolysate. Activated carbons were obtained from Shanghai Activated Carbon Co., Ltd. (Shanghai, China). Macroporous resins X-5, AB-8, S-8, and NKA-9 were purchased from the Chemical Plant of Nankai University (Tianjin, China); HZ816, D101, DA-201C, and HPD-722 were purchased from Zhengzhou Qinshi Sci. \& Tech. Co., Ltd. (Zhengzhou, China). All of them were first soaked in $95.0 \%(\mathrm{v} / \mathrm{v})$ ethanol for $12 \mathrm{~h}$, washed thoroughly with distilled water, and vacuum dried prior to use.

\subsection{Preparation of A. leucoprocta hydrolysate}

The dried A. leucoprocta was pre-treated according to the procedures of Newman (1999) till it touched soft enough. Then it was cut into small pieces, and homogenized on a Twe Ultra-Turrax (IKA) at $18000 \mathrm{rpm}$ for $20 \mathrm{~min}$. The homogenate was fully hydrolyzed at $115^{\circ} \mathrm{C}$ with $6 \mathrm{~mol} / \mathrm{L} \mathrm{HCl}$. The solution was evaporated to remove $\mathrm{HCl}$ in a rotary vacuum evaporator at $70^{\circ} \mathrm{C}$ for three times and the residue was redissolved in $1.5 \mathrm{~L}$ deionized water to obtain A. leucoprocta hydrolysate.

\subsection{Decoloration of A. leucoprocta hydrolysate}

The decolorizing agent (activated carbon or macroporous resin) was added into a conical flask containing $50 \mathrm{~mL}$ of hydrolysate with different $\mathrm{pH}$ adjusted with $6.0 \mathrm{~mol} / \mathrm{L} \mathrm{NaOH}$. After sealing, the conical flasks were placed in a water-bathing constant temperature vibrator at different temperatures and contact times. The solution was then filtered through Whatman glass microfiber filter and the filtrate was collected. The optical densities of the hydrolysate sample solution $\left(O D_{h}\right)$ and the filtrate $\left(O D_{d}\right)$ were measured using a UV2450-type ultraviolet-visible spectrophotometer (Shimadzu, Japan) at $450 \mathrm{~nm}$, respectively. The decoloration ratio was calculated using $D R(\%)=\left(O D_{h}-O D_{d}\right) / O D_{h} \times 100 \%$.

\subsection{Oxidative deamination methods}

$\mathrm{NaNO}_{2}$ oxidization

The $\mathrm{NaNO}_{2}$ solution $(500 \mathrm{~g} / \mathrm{L})$ was added dropwise into $50 \mathrm{~mL}$ decolorized hydrolysate while stirring over $3.5 \mathrm{~h}$ at constant temperature, during which the primary amino acids were selectively oxidized deamination with the formation of hydroxy acids; and imino acids were converted into nitrosamines (Levine, 1959). After stirring for an additional $1 \mathrm{~h}, 50 \mathrm{~mL}$ of concentrated $\mathrm{HCl}$ was added for the regeneration of L-Pro and L-Hyp by hydrolysis of their nitrosamines (Levine, 1959). Subsequently, the reaction solution was concentrated to dryness in a rotary vacuum evaporator, and the residue was evaporated again after addition of $50 \mathrm{~mL}$ deionized water. The re-evaporated residue dissolved in hot ethanol $\left(95 \%, 90{ }^{\circ} \mathrm{C}\right)$ and was filtered twice through Whatman glass microfiber filter to remove the insoluble salts. Followingly, the ethanol in filtrate consisted of soluble amino acids was vacuum rotary evaporated and the residue redissolve in $50 \mathrm{~mL}$ deionized water to yield a solution with L-Pro, L-Hyp and remained $\mathrm{NaCl}$.

To further reduce $\mathrm{NaCl}$ amount, the solution was re-decolorized with activated carbon and then desalinated through column chromatography. The desalination process was performed on glass columns $(20 \mathrm{~cm} \times 1.5 \mathrm{~cm})$ (Bio-Rad, USA) packed with $4.0 \mathrm{~g}$ (dry weight) cation-exchange resin D001 $\left(\mathrm{Na}^{+}\right)$, the re-decolorized solution ( $\mathrm{pH}$ 3.0) flowed through the column at the flow rate of $1.0 \mathrm{~mL} / \mathrm{min}$. The effluent was collected and its conductivity and imino acids concentrations were detected.

\section{$\mathrm{HCl}-\mathrm{HNO}_{3}$ oxidization}

$50 \mathrm{~mL}$ decolorized hydrolysate was vacuum rotary evaporated and the residue redissolved in concentrated $\mathrm{HCl}$, followed by concentrated $\mathrm{HNO}_{3}$. This reaction solution was heated for $5 \mathrm{~min}$ in a boiling water bath and then immediately rotary evaporated. The residue from the nitrosylation reaction containing unreacted imino acids and a mixture of hydroxy acids formed from primary amino acids and their oxidation products, was evaporated again after addition of $10 \mathrm{~mL}$ deionized water. The re-evaporated residue was sequencely dissolved in $1 \mathrm{~mL}$ acetone and $50 \mathrm{~mL}$ diethyl. When the solution was separated into two phases, the decanted organic layer containing hydroxy acids was discarded; the oily residue consisted of a mixture of L-Pro and L-Hyp was treated with a second extraction with $25 \mathrm{~mL}$ ether to remove remaining traces of the hydroxy acids and dissolved in $50 \mathrm{~mL}$ deionized water, generating a solution which could be directedly applied to the column chromatography for L-Pro and L-Hyp separation described below.

\subsection{Ion-exchange process for L-Pro and L-Hyp separation from A. leucoprocta hydrolysate}

For separation of L-Pro and L-Hyp from extract of A. leucoprocta hydrolysate, ion-exchange experiments including dynamic adsorption and desorption processes were carried out on glass columns $(200 \mathrm{~mm} \times 15 \mathrm{~mm})$ (Bio-Rad, USA) wet-packed with cation-exchange resin Dowex 50WX8 (4.0 g, dry weight) (Zhou et al., 2018). Appropriately diluted sample solution 
( $\mathrm{pH}$ 3.0-4.0) was passed through the ion-exchange column at $25^{\circ} \mathrm{C}$ with a flow rate of $1.9 \mathrm{~mL} / \mathrm{min}$ till one of the breakthrough points of L-Hyp or L-Pro occurred. The breakthrough point was defined as the concentration of adsorbate leakage solution was $5 \%$ of its initial concentration. L-Pro and L-Hyp adsorbed on Dowex 50WX8 resin was eluted by $1.0 \mathrm{~mol} / \mathrm{L} \mathrm{HCl}$ solution at a flow rate of $0.10 \mathrm{~mL} / \mathrm{min}$. Eluates were collected for L-Pro and L-Hyp detection.

\subsection{Analysis methods}

The amino acid was detected using an Amino Acid Analyzer (Sykam S-433D, Kleinostheim, Germany) with post column ninhydrin derivatization. L-Pro and L-Hyp were quantified using FMOC pre-column derivatization method with an Agilent 1100 HPLC (Palo Alto, Ca, USA) equipped with a Zorbax Eclipse-AAA column $(150 \mathrm{~mm} \times 4.6 \mathrm{~mm}, 3.5 \mu \mathrm{m})$ (Henderson et al., 2000; Zhou et al., 2018). The recovery yields $(R Y)$ and loss ratios $(L R)$ of imino acids were calculated by Equations 1 and 2 .

$R Y=C_{t} V_{t} / C_{0} V_{0} \times 100 \%$

$L R=\left(1-C_{t} V_{t} / C_{0} V_{0}\right) \times 100 \%$

where $C_{t}$ and $C_{0}$ is the concentration of L-Pro or L-Hyp in the solution after and before treatment, respectively; $V_{t}$ and $V_{0}$ is the solution volume after and before treatment, respectively.

\section{Results and discussion}

\subsection{Amino acid composition of A. leucoprocta}

The composition and content of amino acid were summarized in Table 1 . The protein content in body wall of dry A. leucoprocta was $70.92 \%$, higher than that of other echinoderms, such as
Parastichopus californicus (Liu et al., 2010), Stichopus horrens (Forghani et al., 2012), and S. japonicus (Saito et al., 2002). In the hydroxysate of $A$. leucoprocta, 18 kinds of amino acids were detected, with a total content of $89.2 \%$ (based on the dry weight of A. leucoprocta). Among them, L-glycine is the most abundant amino acid, covering $17.79 \%$ of the dry weight of A. leucoprocta; L-glutamic acid and L-alanine are the second abundant amino acids, each one contributing about $11 \%$ of the dry weight. The results are similar to those of S. japonicus (Cui et al., 2007). The content of total collagen was calculated using a L-Hyp to collagen ratio of 1:13 (Trotter et al., 1995), and the results was $56.9 \%$ of the dry weight, representing $76.3 \%$ of the total protein and indicating that collagen is the main protein of A. leucoprocta. As the essential component of collagen, L-Pro and L-Hyp accounted for $9.15 \%$ and $4.38 \%$ of dry weight, suggesting that low-value $A$. leucoprocta could be served as a potential raw material for L-pro and L-Hyp extraction and preparation.

\subsection{Decoloration of A. leucoprocta hydrolysate}

The decoloration ratio is closely related to decolorizing agent and reaction condition. In this project, activated carbons and macroporous resins were selected, and their decoloration performance under different conditions were tested and compared.

\section{Decoloration with activated carbon}

In our preliminary study, activated carbons granular 769 and powdered W660 were compared, and the powdered W660 exhibited a higher dyes removal ability towards the hydrolysate of A. leucoprocta than that of granular 769 (data not shown). Thus, the subsequent investigations were carried out with powdered W660 as decolorizing agent.

Table 1. Amino acid composition and content in body wall of A. leucoprocta.

\begin{tabular}{|c|c|c|c|}
\hline Amino acid & Content in total amino acids (\%) & Content in protein $(\%)$ & Content in dry A. leucoprocta (\%) \\
\hline L-Hyp & $4.91 \pm 0.23$ & $5.87 \pm 0.14$ & $4.38 \pm 0.17$ \\
\hline L-Pro & $10.26 \pm 0.26$ & $12.28 \pm 0.45$ & $9.15 \pm 0.42$ \\
\hline L-Asp & $7.48 \pm 0.32$ & $8.96 \pm 0.33$ & $6.67 \pm 1.11$ \\
\hline L-Ser & $3.95 \pm 0.15$ & $4.73 \pm 0.28$ & $3.52 \pm 0.12$ \\
\hline L-Glu & $12.71 \pm 0.60$ & $15.22 \pm 0.26$ & $11.34 \pm 0.46$ \\
\hline L-Cys & $0.66 \pm 0.04$ & $0.79 \pm 0.13$ & $0.59 \pm 0.01$ \\
\hline L-Val & $2.87 \pm 0.11$ & $3.43 \pm 0.28$ & $2.56 \pm 0.07$ \\
\hline L-Met & $1.51 \pm 0.09$ & $1.81 \pm 0.08$ & $1.35 \pm 0.07$ \\
\hline L-Ile & $3.15 \pm 0.14$ & $3.77 \pm 0.15$ & $2.81 \pm 0.08$ \\
\hline L-Leu & $3.09 \pm 0.14$ & $3.69 \pm 0.17$ & $2.75 \pm 0.08$ \\
\hline L-Arg & $7.07 \pm 0.27$ & $8.46 \pm 0.12$ & $6.30 \pm 0.28$ \\
\hline Total amino acids & - & - & $89.2 \pm 4.10$ \\
\hline Total protein & - & - & $74.5 \pm 2.52$ \\
\hline Collagen & - & $76.3 \pm 3.14$ & $56.9 \pm 1.87$ \\
\hline
\end{tabular}


To achieve a higher decoloration ratio and fewer imino acids loss, the effects of activated carbon dosage, temperature, $\mathrm{pH}$ and treatment time on the decoloration of hydrolysate were investigated. The results were shown in Figure 1. From Figure 1a, we can see that, the decoloration ratio increased with the activated carbon addition dosage, and reached the saturation plateaus when the activated carbon concentrations were $9.00 \mathrm{~g} / \mathrm{L}$; while, imino acids loss percentage increased slowly with the activated carbon concentration in the range of 0.45 $18.00 \mathrm{~g} / \mathrm{L}$. Thus, the addition dosage of activated carbon was selected as $9.00 \mathrm{~g} / \mathrm{L}$ and used in the following tests. As shown in Figure $1 \mathrm{~b}$, decoloration ratio increased when the temperature was elevated from 40 to $60{ }^{\circ} \mathrm{C}$, and was maintained at the highest level at $60-90{ }^{\circ} \mathrm{C}$; however, the imino acids loss was substantially increased as the temperature rised. Thus, $60^{\circ} \mathrm{C}$ was the most suitable temperature for decoloration. As shown in Figure 1c, the highest decoloration ratio and fewest imino acids loss were found when initial $\mathrm{pH}$ of the solution was 3.0. So pH 3.0 was selected for the following tests. As can be seen from Figure 1d, the adsorption capacities of dyes and imino acids increased rapidly in the first $5 \mathrm{~min}$ and varied slowly after $5 \mathrm{~min}$, reaching their maximum values at about $30 \mathrm{~min}$ and $90 \mathrm{~min}$, respectively. Therefore, the optimal decoloration time was recommended as $30 \mathrm{~min}$. Under these optimized conditions, the decoloration ratio reached $95.50 \%$, with L-Pro and L-Hyp recovery yields of $89.9 \%$ and $91.4 \%$, respectively.

\section{Decoloration with resin}

$0.5 \mathrm{~g}$ each of macroporous resins were added into $50 \mathrm{~mL}$ of hydrolysate sample solution. After $12 \mathrm{~h}$ shaking (150 rpm) at $60^{\circ} \mathrm{C}$, the decoloration ability for each macroporous resins was detected and compared. Figure 2 indicated that, four resins (HZ816, D101, AB-8, and HPD-722), especially HZ816 showed a satisfactory performance on dye removal (decoloration ratio $>80 \%$ ) and imino acid recovery ( $>93 \%)$. Thus, HZ816 was selected for decoloration in the following experiments.

The effects of resin HZ816 dosage, temperature, $\mathrm{pH}$, and contact time on decoloration ratio and imino acids loss ratios were investigated and the results were illustrated in Figure 3a-d, respectively. As shown in Figure 3, the most suitable conditions for decoloration with HZ816 were as follows: resin dosage $30 \mathrm{~g} / \mathrm{L}$, temperature $50^{\circ} \mathrm{C}, \mathrm{pH} 3.0$, and treatment time $240 \mathrm{~min}$; in the optimized conditions, the highest decoloration ratio was 88.1\%; and L-Pro and L-Hyp recovery yields were $92.1 \%$ and $93.3 \%$, respectively.

The decoloration ratio and imino acids recovery yields were comparable to those of activated carbon powdered W660. However, the required amount of resin was much higher, and the treatment time were significantly lengthened, indicating that this decoloration process is of low efficiency and high cost. Therefore, activated carbon powdered W660 was more suitable in the decoloration of A. leucoprocta hydrolysate.
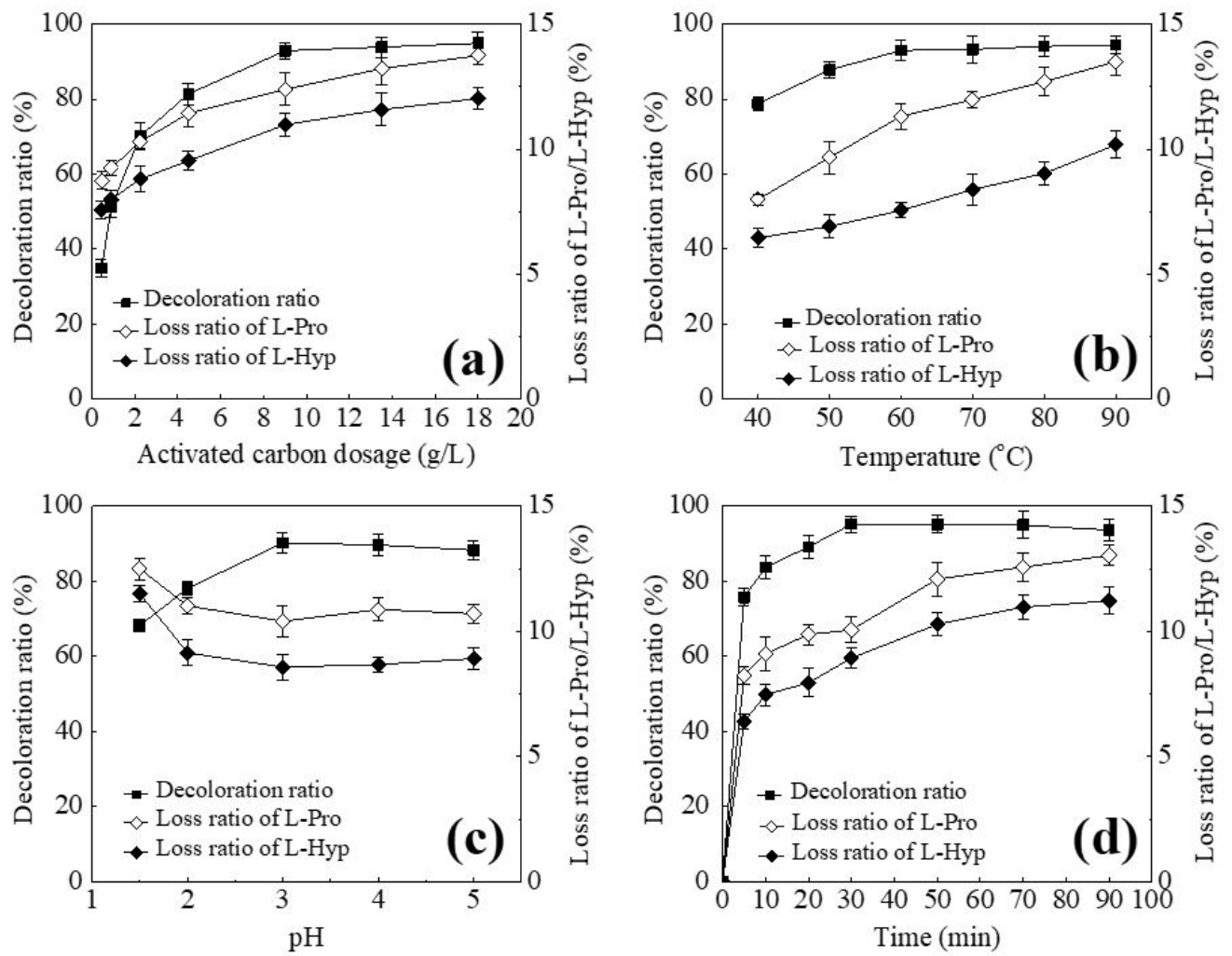

Figure 1. Effect of the decoloration conditions of activated carbon on decoloration ratio and imino acids loss. (a) Activated carbon dosage; (b) decoloration temperature; (c) sample solution $\mathrm{pH}$; (d) treatment time. 


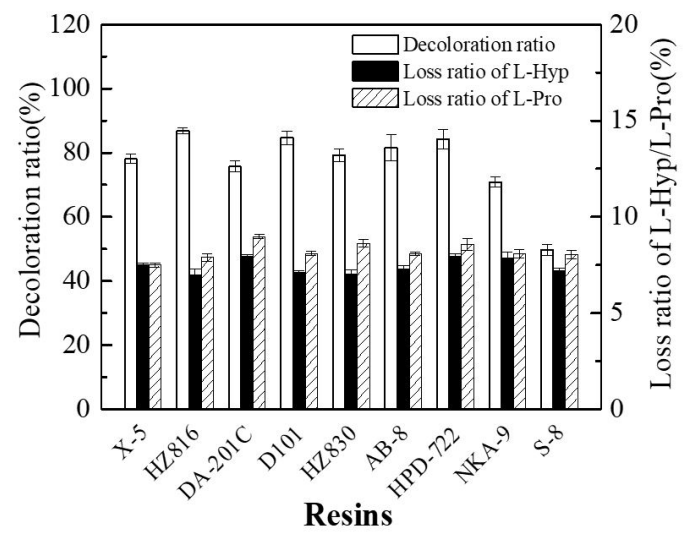

Figure 2. Decoloration ratio and imino acids loss ratio on different macroporous resins.
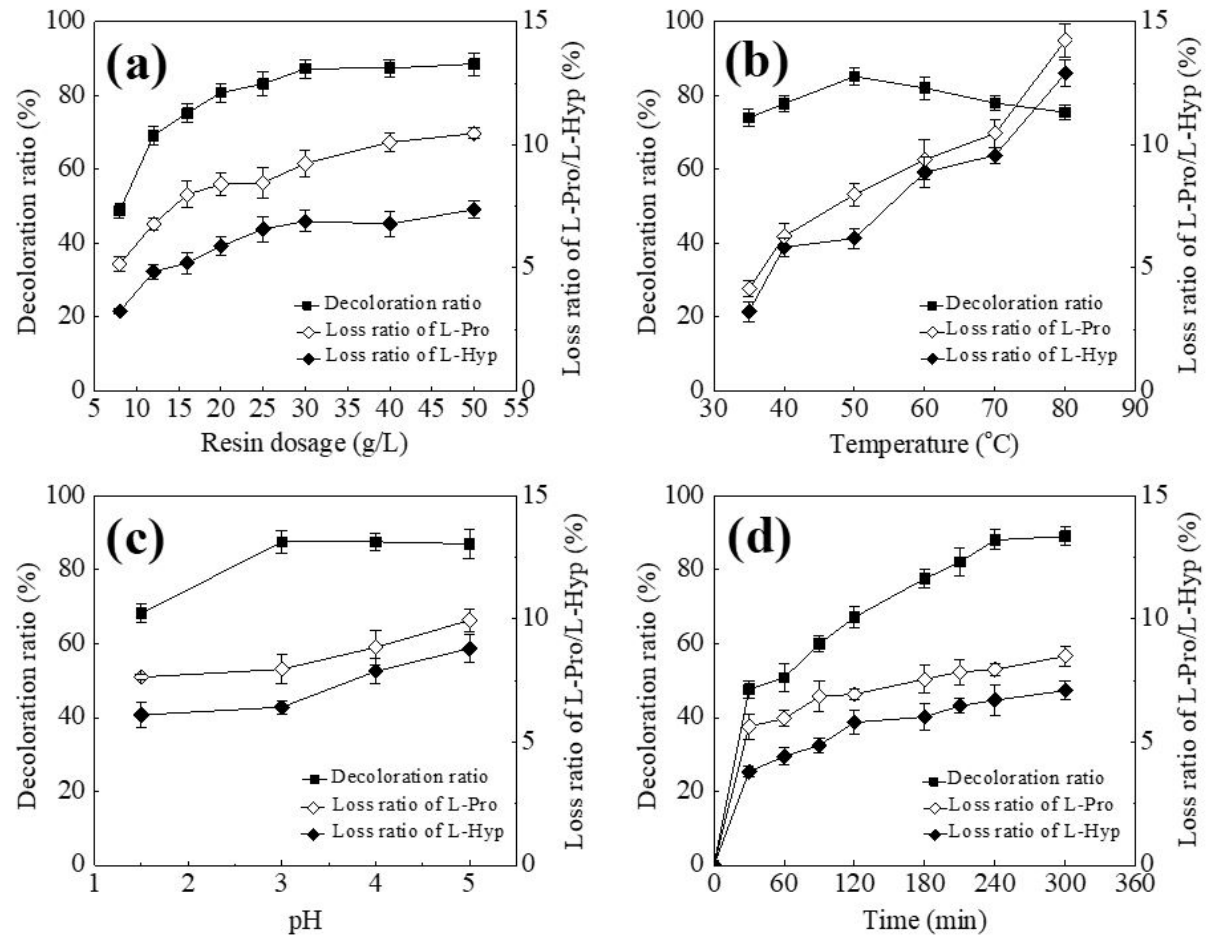

Figure 3. Effect of the decoloration conditions of resin HZ816 on decoloration ratio and imino aicds loss. (a) Resin HZ816 dosage; (b) decoloration temperature; (c) sample solution $\mathrm{pH}$; (d) contact time.

\subsection{Oxidation of decolorized hydrolysate of A. leucoprocta}

The oxidative deamination of $\alpha$-amino acids in the decolorized hydrolysate of A. leucoprocta was performed with two methods. The effects of different methods on primary amino acids broken-down and imino acids loss under different conditions were studied and compared.

\section{Oxidization with $\mathrm{NaNO}_{2}$}

For a complete deamination of $\alpha$-amino acids and less loss of imino acids, the decolorized hydrolysate was first treated with $500 \mathrm{~g} / \mathrm{L} \mathrm{NaNO}_{2}$ solution at different addition amounts and reaction temperatures. As Figure 4a showed, the loss ratio of L-Pro and L-Hyp increased with $\mathrm{NaNO}_{2}$ final concentration from $20 \mathrm{~g} / \mathrm{L}$ to $80 \mathrm{~g} / \mathrm{L}$. However, when the final concentration of $\mathrm{NaNO}_{2}$ was below $60 \mathrm{~g} / \mathrm{L}$, the deamination of primary amino acids was incomplete; many amino acids could be detected in the amino acid analysis (data now shown). Therefore, $60 \mathrm{~g} / \mathrm{L} \mathrm{NaNO}_{2}$ was advised in the following work. As shown in Figure $4 \mathrm{~b}$, increasing the reaction temperature above $40{ }^{\circ} \mathrm{C}$ resulted in a significant imino acid loss; and the complete deamination of primary amino acids was found at $40{ }^{\circ} \mathrm{C}$ and above (data now shown), so $40^{\circ} \mathrm{C}$ was selected as the optimal temperature. The loss ratios of L-Pro and L-Hyp were $18.7 \%$ and $19.8 \%$ respectively at $60 \mathrm{~g} / \mathrm{L} \mathrm{NaNO}_{2}$ and $40^{\circ} \mathrm{C}$. 
$\mathrm{NaNO}_{2}$ has been usually used in deamination of $\alpha$-amino acids, but use of this reagent entails the production of $\mathrm{NaCl}$ (Levine, 1959). Thus, desalination through ion-exchange resin D001 $\left(\mathrm{Na}^{+}\right)$were conducted followingly. As a result, most of $\mathrm{Na}^{+}$was removed, and the conductivity decreased to $10.04 \mathrm{~ms} / \mathrm{cm}$ from $38.12 \mathrm{~ms} / \mathrm{cm}$; However, considerable amounts of extra L-Pro and L-Hyp were also lost. A total loss of 38.5\% (L-Pro) and $34.4 \%$ (L-Hyp) was detected in the desalinated solution.

\section{$\mathrm{HCl}-\mathrm{HNO}_{3}$ oxidization}

In this method, different volume ratios (3:1, 4:1, and 5:1) of concentrated $\mathrm{HCl}(36 \%)$ and $\mathrm{HNO}_{3}(65 \%)$ in a total volume of $60 \mathrm{~mL}$ were tried. As shown in Figure 5a, the best recovery of L-Pro and L-Hyp was obtained at 4:1 $\left(\mathrm{HCl}: \mathrm{HNO}_{3}, \mathrm{v} / \mathrm{v}\right)$; with each volume ratio, the primary amino acids were all completely deaminated in $60 \mathrm{~mL}$ of total solution volume (data not shown); this indicated that, the amounts of $\mathrm{HCl}$ and $\mathrm{HNO}_{3}$ were sufficicent for oxidation reaction of the hydrolysate.

With the volume ratio of 4:1 $\left(\mathrm{HCl}: \mathrm{HNO}_{3}, \mathrm{v} / \mathrm{v}\right)$, the effect of different total volumes $(25,40,50,60$, and $75 \mathrm{~mL})$ on primary amino acids oxidation and imino acids loss were detected. From Figure 5b, we can see that increasing the total volume caused more loss of imino acids, suggesting that low volume is in favor of maintaining L-Pro and L-Hyp. However, when the total volume was below $50 \mathrm{~mL}$, the primary amino acids were incompletely breakdown (Figure 6). Therefore, the total volume was recommended as $50 \mathrm{~mL}$ with $4: 1$ of $\mathrm{HCl}$ and $\mathrm{HNO}_{3}(\mathrm{v} / \mathrm{v})$.

Different from $\mathrm{NaNO}_{2}$ oxidization, the residues after $\mathrm{HCl}$ and $\mathrm{HNO}_{3}$ treatment were volatile, no salts were introduced into the solution. After extraction with organic solvent, the loss ratios of L-Pro and L-Hyp were $15.2 \%$ and $13.8 \%$, respectively, obviously lower than those of $\mathrm{NaNO}_{2}$ oxidization.

\subsection{Extraction and separation of L-Pro and L-Hyp from hydrolysate of A. leucoprocta}

For efficient extraction of L-Pro and L-Hyp from A. leucoprocta hydrolysate, three repeated decolorization and oxidative deamination experiments were performed under the optimized conditions obtained in this work. After A. leucoprocta was fully hydrolyzed, $1500 \mathrm{~mL}$ hydrolysate with $\mathrm{pH} 1.5$ was yielded. L-Pro and L-Hyp in the hydrolysate of A. leucoprocta were detected and the results were $6.65 \mathrm{~g} / \mathrm{L}$ and $3.18 \mathrm{~g} / \mathrm{L}$, respectively. After treatment with $9.00 \mathrm{~g} / \mathrm{L}$ activated carbon powdered W660 at $60^{\circ} \mathrm{C}$ for $30 \mathrm{~min}$, a clear, light yellow solution with $6.09 \mathrm{~g} / \mathrm{L} \mathrm{L}-\mathrm{Pro}$ and $2.95 \mathrm{~g} / \mathrm{L}$ L-Hyp was yielded, in which large amounts of other amino acids also existed; after oxidative deamination of decolorized A. leucoprocta hydrolysate with $1500 \mathrm{~mL} \mathrm{HCl}-\mathrm{HNO}_{3}(4: 1, \mathrm{v} / \mathrm{v})$ and organic solvent extraction, an extraction solution with
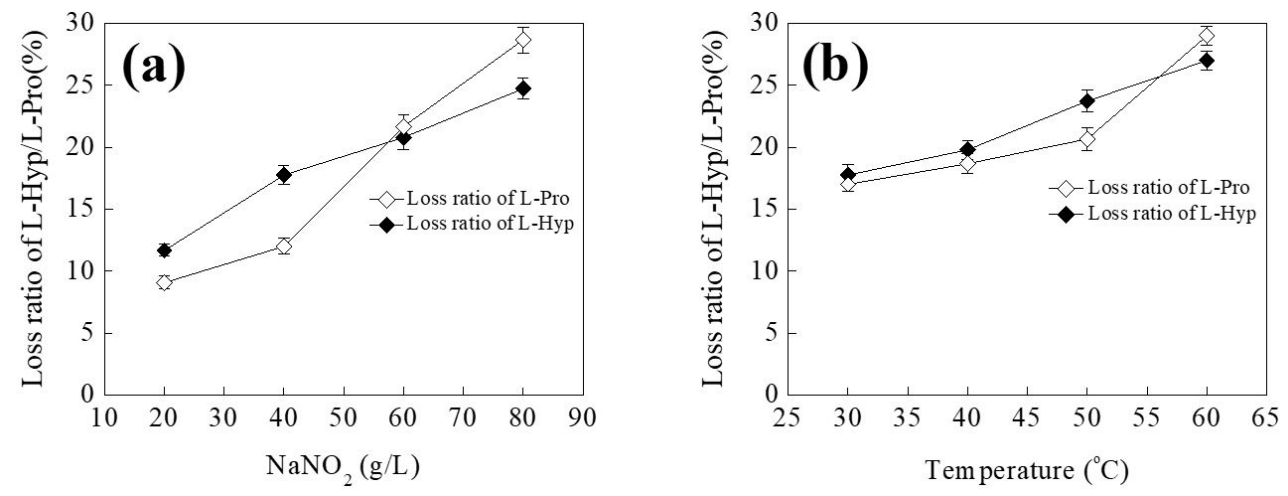

Figure 4. Effect of the $\mathrm{NaNO}_{2}$ concentrations (a) and temperatures (b) on loss ratio of L-Pro and L-Hyp.
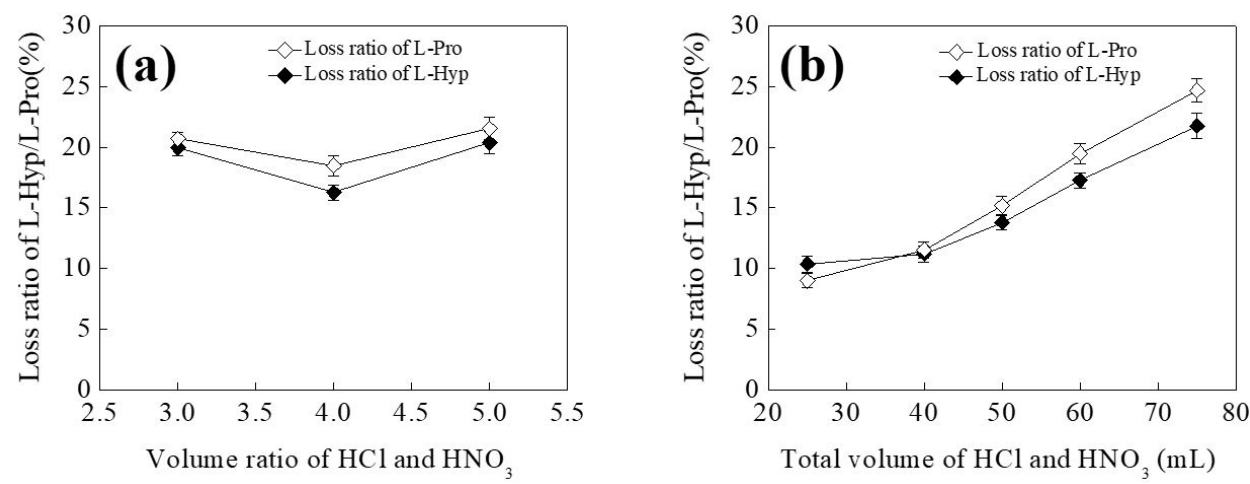

Figure 5. Effect of the volume ratios (a) and total volumes of $\mathrm{HCl}$ and $\mathrm{HNO}_{3}$ (b) on imino acids loss. 

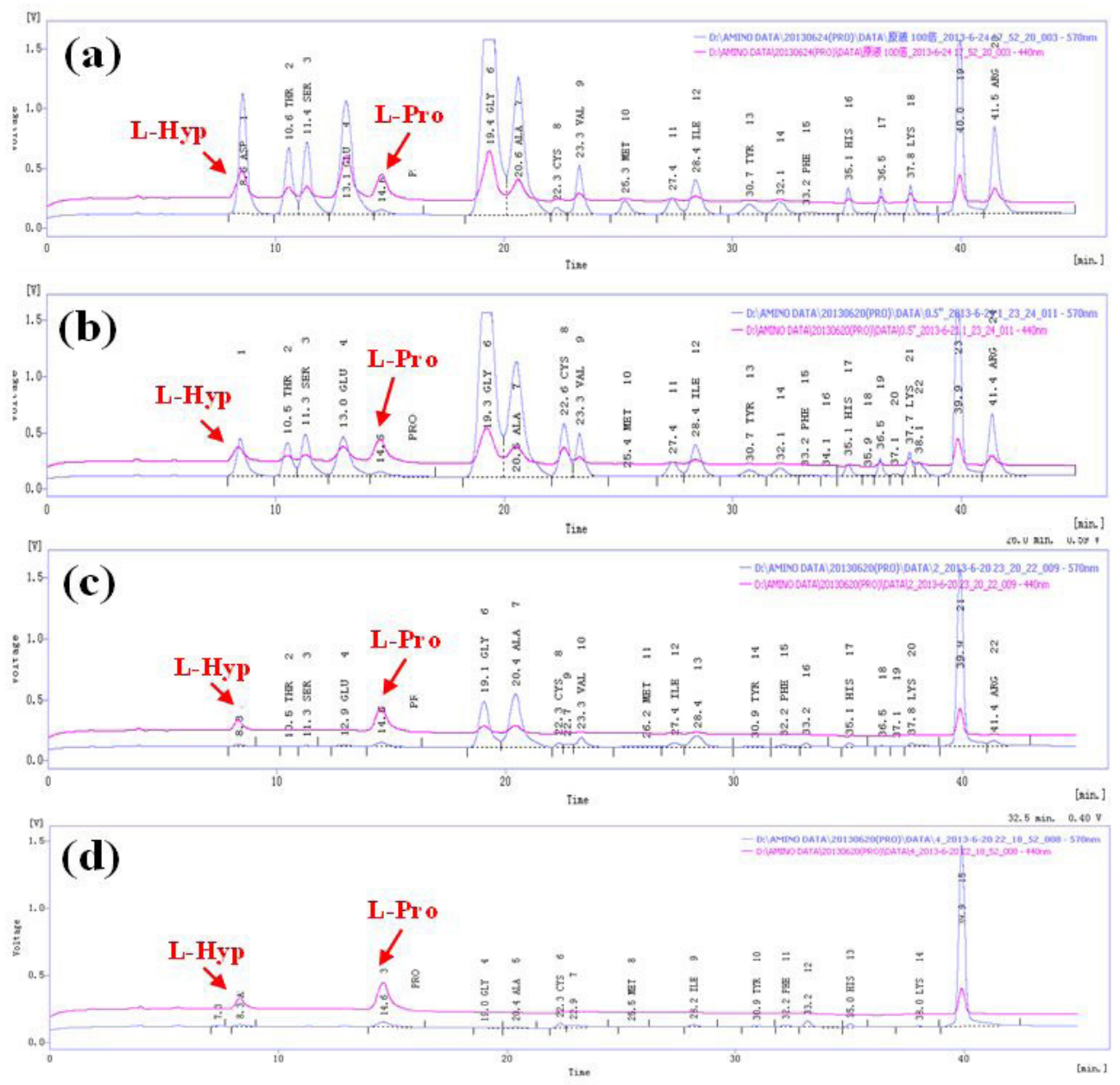

Figure 6. Amino acid composition of extract solution after treatment of different total volumes of $\mathrm{HCl}$ and $\mathrm{HNO}_{3}(4: 1, \mathrm{v} / \mathrm{v})$. (a), $0 \mathrm{~mL}$ (b), $25 \mathrm{~mL}$; (c), $40 \mathrm{~mL}$; (d) $50 \mathrm{~mL}$.

$5.07 \mathrm{~g} / \mathrm{L} \mathrm{L}$-Pro and $2.51 \mathrm{~g} / \mathrm{L}$ L-Hyp was generated. The recovery yields of L-Pro and L-Hyp from A. leucoprocta hydrolysate were $76.3 \%$ and $78.8 \%$, respectively.

With the final extraction solution, an ion-exchange process for L-Pro and L-Hyp separation and purification was carried on with cation-exchange resin Dowex 50WX8. Through dynamic adsorption and desorption, the purities of L-Pro and L-Hyp in their corresponding eluates reached $94.33 \%$ and $95.75 \%$, respectively. The final recovery yields of L-Pro and L-Hyp from A. leucoprocta hydrolysate were $71.1 \%$ and $70.5 \%$, respectively. Therefore, the optimized processes including decolorization and oxidative deamination in this study were suitable for use in a large-scale process to recover L-Pro and L-Hyp from an amino acids mixture.

\section{Conclusions}

An efficient extraction of L-Pro and L-Hyp from hydrolysate of low-value sea cucumber A. leucoprocta was successfully achieved in this study. In the decoloration process, the decoloration performance of two decolorizing agents including activated carbon powdered W660 and macroporous resin HZ816 under various conditions were tested and compared. The result showed that activated carbon powdered W660 was more suitable for decoloration of A. leucoprocta. In the $\alpha$-amino acids oxidative deamination process of the decolorized hydrolysate of A. leucoprocta, the oxidation performances and imino acids loss yields with $\mathrm{NaNO}_{2}$ and $\mathrm{HCl}-\mathrm{HNO}_{3}$ as oxidants under different conditions were investigated. The results indicated that, compared with $\mathrm{NaNO}_{2}, \mathrm{HCl}-\mathrm{HNO}_{3}$ exhibited better oxidization performance with complete primary amino acids broken down and fewer imino acids loss. After decolorization and oxidative deamination under their optimized conditions, an extraction solution containing $5.07 \mathrm{~g} / \mathrm{L}$ L-Pro and $2.51 \mathrm{~g} / \mathrm{L}$ L-Hyp with high recovery yields of L-Pro (76.3\%) and L-Hyp (78.8\%) from A. leucoprocta hydrolysate was obtained, which was directly used for L-Pro and L-Hyp separation in ion-exchange process with final recovery yields of $71.1 \%$ (L-Pro) and 70.5\% (L-Hyp) and high purities of $94.33 \%$ (L-Pro) and 95.75\% (L-Hyp), respectively. The results obtained in this study can be referenced for the extraction of L-Pro and L-Hyp from other low-value materials. 


\section{Acknowledgements}

The authors gratefully acknowledge the financial support of the National Natural Science Foundation of China (No. 31500031), the Natural Science Foundation of Zhejiang Province (No. LQ14B060004), and the Natural Science Foundation of Zhejiang University of Technology (No. 2012XY010).

\section{References}

Bhattacharjee, A., \& Bansal, M. (2005). Collagen structure: the madras triple helix and the current scenario. International Union of Biochemistry and Molecular Biology Life, 57(3), 161-172. http:// dx.doi.org/10.1080/15216540500090710. PMid:16036578.

Chen, S., White, C. E., diCenzo, G. C., Zhang, Y., Stogios, P. J., Savchenko, A., \& Finan, T. M. (2016). L-Hydroxyproline and D-proline catabolism in Sinorhizobium meliloti. Journal of Bacteriology, 198(7), 1171-1181. http://dx.doi.org/10.1128/JB.00961-15. PMid:26833407.

Clark, H. L. (1938). Echinoderms from Australia (Vol. 55, 596 p., Memoirs of the Museum of Comparative Zoology of the Harvard College). Cambridge: Cambridge Mass.

Cui, F., Xue, C., Li, Z., Zhang, Y., Dong, P., Fu, X., \& Gao, X. (2007). Characterization and subunit composition of collagen from the body wall of sea cucumber Stichopus japonicus. Food Chemistry, 100(3), 1120-1125. http://dx.doi.org/10.1016/j.foodchem.2005.11.019.

Forghani, B., Ebrahimpour, A., Bakar, J., Abdul Hamid, A., Hassan, Z., \& Saari, N. (2012). Enzyme hydrolysates from Stichopus horrens as a new source for angiotensin-converting enzyme inhibitory peptides. Evidence-Based Complementary and Alternative Medicine, 2012, 236384-236384. http://dx.doi.org/10.1155/2012/236384. PMid:22927875.

Henderson, J. W., Ricker, R. D., Bidlingmeyer, B. A., \& Woodward, C. (2000). Rapid, accurate, sensitive, and reproducible HPLC analysis of amino acids. Amino acid analysis using Zorbax Eclipse-AAA columns and the Agilent 1100 HPLC (Agilent Technologies Technical Note 5980-1193E). Santa Clara: Agilent.

Huang, C. Y., Kuo, J. M., Wu, S. J., \& Tsai, H. T. (2016). Isolation and characterization of fish scale collagen from tilapia (Oreochromis sp.) by a novel extrusion-hydro-extraction process. Food Chemistry, 190, 997-1006. http://dx.doi.org/10.1016/j.foodchem.2015.06.066. PMid:26213067.

Huang, H., Wu, J. Y., \& Wu, J. H. (2007). Heavy metal monitoring using bivalved shellfish from Zhejiang coastal waters, east China sea. Environmental Monitoring and Assessment, 129(1-3), 315-320. http://dx.doi.org/10.1007/s10661-006-9364-9. PMid:17057972.

Klein, C., \& Hüttel, W. (2011). A simple procedure for selective hydroxylation of L-proline and L-pipecolic acid with recombinantly expressed proline hydroxylases. Advanced Synthesis \& Catalysis, 353(8), 1375-1383. http://dx.doi.org/10.1002/adsc.201000863.

Levine, M. (1959). A new method for isolation of hydroxy-L-proline and L-proline from gelatin. The Journal of Biological Chemistry, 234(7), 1731-1732. PMid:13672954.

Li, Z., Wang, B., Chi, C., Zhang, Q., Gong, Y., Tang, J., Luo, H., \& Ding, G. (2013). Isolation and characterization of acid soluble collagens and pepsin soluble collagens from the skin and bone of Spanish mackerel (Scomberomorous niphonius). Food Hydrocolloids, 31(1), 103-113. http://dx.doi.org/10.1016/j.foodhyd.2012.10.001.

Lin, S., Chen, L., Jia, Y., Xiao, H., Xue, Y., \& Zheng, Y. (2018). Distribution and chemoenzymatic removal of heavy metals in sea cucumber Acaudina leucoprocta. Food Science and Technology Research, 24(2), 223-229. http://dx.doi.org/10.3136/fstr.24.223.

Lin, S., Xue, Y.-P., San, E., Keong, T. C., Chen, L., \& Zheng, Y.-G. (2017). Extraction and characterization of pepsin soluble collagen from the body wall of sea cucumber Acaudina leucoprocta. Journal of Aquatic Food Product Technology, 26(5), 502-515. http://dx.doi.org/10.108 $0 / 10498850.2016 .1222560$.

Lin, Y.-K., \& Kuan, C.-Y. (2010). Development of 4-hydroxyproline analysis kit and its application to collagen quantification. Food Chemistry, 119(3), 1271-1277. http://dx.doi.org/10.1016/j.foodchem.2009.08.009.

Liu, Y., Zhou, D., Liu, Z., Lu, T., Song, L., Li, D., Dong, X., Qi, H., Zhu, B., \& Shahidi, F. (2018). Structural and biochemical changes in dermis of sea cucumber (Stichopus japonicus) during autolysis in response to cutting the body wall. Food Chemistry, 240, 1254-1261. http://dx.doi.org/10.1016/j.foodchem.2017.08.071. PMid:28946250.

Liu, Y., Zhou, D., Ma, D., Liu, Z., Liu, Y., Song, L., Dong, X., Li, D., Zhu, B., Konno, K., \& Shahidi, F. (2017). Effects of endogenous cysteine proteinases on structures of collagen fibres from dermis of sea cucumber (Stichopus japonicus). Food Chemistry, 232, 10-18. http://dx.doi.org/10.1016/j.foodchem.2017.03.155. PMid:28490052.

Liu, Z., Oliveira, A. C., \& Su, Y. C. (2010). Purification and characterization of pepsin-solubilized collagen from skin and connective tissue of giant red sea cucumber (Parastichopus californicus). Journal of Agricultural and Food Chemistry, 58(2), 1270-1274. http://dx.doi. org/10.1021/jf9032415. PMid:20085374.

Minh Thuy, T., Okazaki, E., \& Osako, K. (2014). Isolation and characterization of acid-soluble collagen from the scales of marine fishes from Japan and Vietnam. Food Chemistry, 149, 264-270. http://dx.doi.org/10.1016/j.foodchem.2013.10.094. PMid:24295705.

Muralidharan, N., Jeya Shakila, R., Sukumar, D., \& Jeyasekaran, G. (2013). Skin, bone and muscle collagen extraction from the trash fish, leather jacket (Odonus niger) and their characterization. Journal of Food Science and Technology, 50(6), 1106-1113. http://dx.doi. org/10.1007/s13197-011-0440-y. PMid:24426022.

Newman, J. M. (1999). Dry ingredient know-how: unusual ingredients. Flavor and Fortune, 6(4), 15-16.

Saito, M., Kunisaki, N., Urano, N., \& Kimura, S. (2002). Collagen as the major edible component of sea cucumber (Stichopus japonicus). Journal of Food Science, 67(4), 1319-1322. http://dx.doi. org/10.1111/j.1365-2621.2002.tb10281.x.

Shan, E., Lin, S., Xue, Y., Zhou, H., \& Zheng, Y. (2013). Study on technology of removing heavy metals from east sea cucumber (Acaudina leucoprocta) (Chinese). Science and Technology of Food Industry, 34(16), 239-244.

Trotter, J. A., Lyons-Levy, G., Thurmond, F. A., \& Koob, T. J. (1995). Covalent composition of collagen fibrils from the dermis of the sea cucumber, Cucumaria frondosa, a tissue with mutable mechanical properties. Comparative Biochemistry and Physiology. Part A, Physiology, 112(3), 463-478. http://dx.doi.org/10.1016/0300-9629(95)02015-2.

Watanabe, S., Hiraoka, Y., Endo, S., Tanimoto, Y., Tozawa, Y., \& Watanabe, Y. (2015). An enzymatic method to estimate the content of L-hydroxyproline. Journal of Biotechnology, 199, 9-16. http://dx.doi. org/10.1016/j.jbiotec.2015.01.026. PMid:25678137.

Xue, Y., Cao, C., \& Zheng, Y. (2018). Enzymatic asymmetric synthesis of chiral amino acids. Chemical Society Reviews, 47(4), 1516-1561. http://dx.doi.org/10.1039/C7CS00253J. PMid:29362736.

Yi, Y., Sheng, H., Li, Z., \& Ye, Q. (2014). Biosynthesis of trans-4hydroxyproline by recombinant strains of Corynebacterium glutamicum and Escherichia coli. BMC Biotechnology, 14(1), 44. http://dx.doi. org/10.1186/1472-6750-14-44. PMid:24885047.

Zhou, H., Zhang, Y., Xue, Y., Lin, S., \& Zheng, Y. (2018). Separation and purification of L-proline and L-hydroxyproline from the hydrolysate of sea cucumber Acaudina leucoprocta. Journal of Chemical Technology and Biotechnology, 93(12), 3543-3552. http:// dx.doi.org/10.1002/jctb.5727. 